343.983:81

811.163.41'33

https://doi.org/10.18485/sj.2021.26.1.9

BRANKA L. MILENKOVIĆ*

University of Kragujevac

Faculty of Philology and Arts
Оригинални научни рад

Примљен: 13. 10. 2020.

Прихваћен: 12. 1. 2021.

\title{
DETECTING DECEPTION THROUGH HEDGING IN FORENSIC ANALYSIS OF WRITTEN STATEMENTS
}

Forensic linguistics is a field of linguistic analysis of discourse, with the implementation in law and criminal investigation. Language analysis establishes a foreground for the forensic investigation that may yield significant conclusions in relation to psychological analysis of behavior and mental processes of a subject. Through the analysis of language items in a discourse it is possible to detect the linguistic code of the speaker/writer and therefore distinguish the deviations from the norm of the speaker/writer. These deviations can be regarded as indications when the subject is being deceitful and lacking commitment in relation to his/her claims and actions. This avoidance in writing is frequently accomplished by the use of hedging discourse markers. The purpose of this study is to analyze an officially written statement on the issue of sexual assault, collected during a criminal investigation by the police officials in the Ministry of Interior in Serbia, in order to illustrate how hedging and lack of commitment in forensic analysis may be an indictment of deception. Results of the study show that the purpose of hedging strategy for distancing in the forensic analysis of written statements is significant in relation to the Main Issue (MI: the criminal conduct), implying that deception may be possible, providing a significant input for further criminal investigation.

Key words: forensic linguistics, forensic analysis of written statements, strategic competence, Commitment to content, hedging 


\section{INTRODUCTION TO FORENSIC LINGUISTICS AND FORENSIC ANALYSIS}

Forensic linguistics is a fairly novel, but a significant branch of Applied linguistics, relating to the field of science that has a full potential of its applicative purpose. It is

"the application of linguistic knowledge to a particular social setting, namely the legal forum (from which the word forensic is derived). In its broadest sense we may say that Forensic Linguistics is the interface between language, crime and law, where law includes law enforcement, judicial matters, legislation, disputes or proceedings in law, and even disputes which only potentially involve some infraction of the law or some necessity to seek a legal remedy." (Olsson 2008: 3)

Coulthard and Johnson (2007: 6) indicate that early forensic linguistic research originated in a wide range of disciplines, from linguistics to law, psychology, anthropology and sociology and it included topics such as handwriting analysis, forensic phonetics and the role of the linguist as an expert in court, covering work in Australia, Europe and North America. (Coulthard \& Johnson 2007: 6) We are therefore, witnesses of forensic linguistics being a very diverse and multi-/cross-disciplinary field of research and practice.

In addition to a diverse disciplinary field, according to the belief of a lawyer and a linguist, Peter Tiersma, the forensic science is not only focused on resolving criminal cases, because forensic expertise can also be used in court defense during a case trial. (in Nikolić-Novaković 2017: 26-27) In anglo-saxon legal systems the defense can invite their expert to refute the evidence. (Nikolić-Novaković 2017:27) In those cases a professional forensic linguist can be summoned and asked for his views as an expert witness in a trial requiring linguistic analysis of the evidence or material relating to the case being held. (Houtman \& Suryati 2018: 219)

Thus, we can conclude that forensic linguistics is a sub-field of linguistics that is particularly engaged with professional and institutional interaction in legal contexts. (Coulthard, Johnson \& Wright 2017: 14)

\subsection{Early days of Forensic Linguistics}

The discipline of forensic linguistics is not a recent field of discovery and it has first been introduced by a Swedish linguist Jan Svartvik in 1960s, yet it remains under-researched and not fully adhered to in scientific papers. Forensic linguistics reaches the level of establishment as a discipline, on the academic and professional grounds, upon the foundation of the International Association of Forensic Linguists in 1993 and the following year, by the introduction of an authoritative journal entitled International Journal of Speech, Language, and the Law. (Houtman \& Suryati 2018: 218-219) There has been a growing amount of research initiated in the field 
ever since, but also the field has yielded master's degree programs in forensic linguistics at the universities in UK and Spain. (Houtman \& Suryati 2018: 218-219)

However, in order to fully understand the vast spectrum of forensic linguistics application, we will illustrate the primary development of the discipline. This scientific field came into focus over the years when linguists were invited to analyze language samples in some criminal cases that became well-known for the outcome of these analysis. Namely, some of the most famous cases where linguistic analysis contributed to the investigation were:

1. The case of Timothy John Evans (1953, UK) who was accused of murdering his wife and child, found guilty and hanged at Pentonville Prison. Following his execution, in 1960s, a journalist Ludovic Kennedy observed a discrepancy in the statements Evans allegedly gave the police and linguist Svartvik was commissioned to analyze these statements. It was proven that the statements differed in styles, one being an educated written style and the other being a spoken style, concluding that Evans could not have dictated the statements attributed to him, but that there was an influx of police register. (Olsson 2008: 4-7)

2. The case of Ernesto Miranda (1963, US) who was convicted of armed robbery, but appealed on the grounds that he did not understand his right to remain silent or to have an attorney present at the time of questioning. The Court Appeal overturned his conviction in 1966 and Professor Roger Shuy raised a discussion about the interrogation process and how coercive the very nature of questioning is. (Olsson 2008: 4-7)

3. In 1994 in US there was a case involving a dispute over the status of a trademark. In this case the linguists were Genine Lentine and Roger Shuy (according to Levi, 1994 in Olsson 2008: 7) and they were involved in the case of Quality Inns International who announced their intention of opening a chain of economy hotels to be called McSleep. McDonald's claimed that the attachment of the $M c$ prefix to many unprotected nouns, such as Fries in $M c$ Fries, Nuggets in $M c$ Nuggets, etc., barred Quality Inns from the use of $M c$ prefix. McDonald's claimed that they have originated the process of attaching unprotected words to the $M c$ prefix and run advertising campaigns which illustrated this. The judgement was ultimately made on behalf of the plaintiff and the Quality International Inns were not able to launch their chain of motels under the McSleep banner. (Olsson 2008: 7)

These are only some of the cases that demonstrate early application of forensic linguistic analysis, allowing the criminal investigation and even belated cases to be observed from a new perspective and to be granted closures. 
It is significant to note that linguistic methods in legal questions may be applied in various linguistic theories and to analysis of different language samples in an inquiry (Olsson 2008: 3).

Some examples that illustrate the use of questions in forensic linguistics (McMenamin 2002) are:

- Phonetics: Is the accused killer's voice on the 911 recording reporting the crime? (911 call)

- Semantics: What does it mean to die by accident, ie. is the sudden infant death and accident? (meaning of accident)

- Pragmatics: Does it make any sense to say that someone did not commit genocide, just acts of genocide? (meaning of genocide)

- Stylistics: Who did, or did not write that ransom note found in the JonBenét Ramsey home? (authorship of the ransom note)

- Discourse analysis: If a detective asks a suspect, "... do you want to speak with us about why you were arrested?" is the suspect waiving his right not to speak by answering, "Yes, I would like to know why I was arrested?" (suspect waiver of rights)

- Trademarks: Does McDonald's own the Mc at the beginning of my last name? (McDonald's Mc)

Thus, the forensic linguist may quote observations from research undertaken in fields as diverse as language and memory studies, Conversation Analysis, Discourse Analysis, theory of grammar, Cognitive Linguistics, Speech Act Theory, etc. (Olsson 2008: 3-4) The reason for this reliance on a broad spectrum of linguistic fields is understandable: the data the linguist receives for analysis may require that something is said about how the average person remembers language, how conversations are constructed, the kinds of moves speakers or writers make in the course of a conversation or a written text, or they may need to explain to a court some aspects of phrase or sentence structure. (Olsson 2008: 3-4)

According to Roger Shuy (in Nikolić-Novaković 2017: 68), in order for someone to be an expert witness in court, that person must be an expert in the field, because their expertese will be based on their knowledge of the discipline, which is in this case the field of linguistics.

Finally, we will relate to the distinction between the oral and the written text that can be used for forensic linguistic analysis. It is interesting to note that, as Tiersma (2001) states:

"in Anglo-Saxon times legal language was entirely oral, with written text, when it eventually came to be used, serving at first only as a record of what had already been performed orally: What mattered was what was said by the participants, not what was written by a scribe. The written documents were merely evidentiary of the oral ceremony, rather than operative or dispositive legal documents in the modern sense... However, over time, the written docu- 
ment, instead of being simply a record of what had already been accomplished orally, that is the performative act, came to constitute the performative act itself." (Coulthard, Johnson \& Wright 2017: 31-32)

As this paper is focused on the analysis of the written discourse, obtained from the corpus of written statements of subjects who have undergone the police interrogation process, we are primarily concerned with the aforementioned 'moves' the writer makes in a written text. These (sub)conscious 'moves' present the highlights of the written statement because they serve as indicators of possible deception and they are used as clues for further police investigation in the criminal cases.

\section{SCIENTIFIC CONTENT ANALYSIS (SCAN) AND LANGUAGE ANALYSIS}

In order to accomplish the forensic analysis of written statements one of the frequently used scanning methods is certainly the Scientific Content Analysis method (SCAN), an analytical technique developed by Avinoam Sapir (2005), a former Israeli polygraph examiner, based on his experience with polygraph examinees. Reflecting on the difference in the language of the people who tell the truth and/or those who lie use, Sapir developed a criteria that, according to him, assist in differentiating between true and fabricated statements. (Bogaard, Meijer, Vrij \& Merckelbach 2016)

The SCAN method, although it is occasionally criticized for its validity, lack of theoretical basis and general lack of scientific research data (Nahari et al., 2012; Bogaard et al., 2014a; Vanderhallen et al., 2015, in Bogaard, Meijer, Vrij \& Merckelbach 2016), remains as one of the frequently applied methods worldwide (eg. Australia, Belgium, Canada, Israel, Mexico, UK, US, the Netherlands, Qatar, Singapore, South Africa) (Bogaard, Meijer, Vrij \& Merckelbach 2016) ${ }^{1}$. However, only six published studies examined the validity of SCAN (Driscoll, 1994; Porter and Yuille, 1996; Smith, 2001; Nahari et al., 2012; Bogaard et al., 2014a; Vanderhallen et al., 2015) of which only four were published in peer reviewed journals. (Bogaard, Meijer, Vrij \& Merckelbach 2016) For this purpose, the present study may contribute to further insight into how language analysis, focusing on one of the SCAN criteria, can support criminal and law investigation in the Serbian police investigation process.

Due to its immense application among the investigator officials, in this research we have opted to analyze it in relation to one linguistic item and to attempt to observe its applicability in deceitful statements.

\footnotetext{
${ }^{1}$ retrieved from www.lsiscan.com/id29.htm, in Bogaard, Meijer, Vrij \& Merckelbach 2016
} 
As telling a lie is a more cognitively demanding activity than telling the truth, due to the fabricated content that the person is creating by using his/her imagination, it is believed that the person may expose him/herself in the written statement involuntarily, and allow the forensic analyst to read between the lines and draw conclusions regarding the deceptive segments of the written statement.

According to Sapir (1995, in Smith 2001: 9)

"when people are given the choice to give their own explanation in their own words, they would choose to be truthful" and that "it is very difficult to lie with commitment... a person can kill, rob a bank, set a fire, steal money, but a person cannot actually lie".

Writing represents a personal journey of introspective analysis and the writer needs to make various choices during the writing process in terms of the language resources used, committing him/herself more or less to the claims he/she is making. According to Smith (2001: 9), some of these choices are constrained by the requirements of the rules of the language system in which the communication is cast, whilst others are dependent upon the author's linguistic knowledge, the context of the communication and other personal influences. It is these determinants of choice, which are open to each author, that will affect both the form and content of language behavior. In short, they form the 'linguistic code' for an author. (Smith 2001: 9)

\subsection{Linguistic code and linguistic fingerprint}

The linguistic code of the author is the revealing component that is expected to establish the basis for further police investigation. Thus, whereas in principle any speaker can use any word at any time, in fact they tend to make typical and individuating co-selections of preferred words. This implies that it should be possible to devise a method of linguistic fingerprinting, in other words that the linguistic 'impression' created by a given speaker should be usable, just like a signature, to identify them. (Coulthard, Johnson \& Wright 2017: 15)

Linguistic fingerprint is a notion put forward by some scholars that each human being uses language differently, and that this difference between people can be observed just as easily and surely as a fingerprint (Olsson 2008: 26). According to this view, the linguistic fingerprint is the collection of markers which stamps a speaker/writer as unique. However, although the linguistic fingerprint is a powerful concept with great attractions for law enforcement and other agencies worldwide, there is so far little hard evidence to support the notion. (Olsson 2008: 26) As eagerly as science attempts to find means of identifying authorship with ultimate precision, forensic linguistics in its goals only offers supportive evidence that may, in combination with other forensic methods, provide sufficient evidence for the accusation of a perpetrator. 


\subsection{Conducting SCAN analysis through linguistic features}

According to Sapir criteria (2005) there are 12 linguistic features that may mark the written statement as a deceitful one (some of them relate to the social introductions, structure analysis, use of subjective/objective time, presence/absence of pronouns, presence/absence of specific content details etc.), however these are only instances of potential of deception and the withholding of relevant information, which does not claim to identify that the author is lying (Smith 2001: 9). However, insight into the potential of deception certainly traces a path for the interrogation process that follows, with the forensic analyst indicating the specific spot in the written statement which needs to be addressed further.

It is important to note the procedural aspect of obtaining the written statement. As Sapir insists on the 'pure version' of the statement (Sapir 2005 in Smith 2001), this means that the written report should not be contaminated by any means (the intrusion with questions, suggestions, clarification or else) by the police officials. This relates to the common practice that is frequented during the police investigation, where police officials demand from their suspects/victims/witnesses to dictate their report instead of writing it, and while the police official records their statement as they speak. Here we have the example of the police register, which is regarded to be the language used for the paraphrasing the police officials use when interrogating a subject and when recording his statement. (Olsson 2008: 5) Police register may intrude in the statement, as most of the time police officials paraphrase in their own words the dictated statements, and therefore evidently contaminate the "pure version' of the story Sapir insist on. Therefore, this type of police report may not be useful for forensic analysis and it may fail to exhibit the linguistic criteria that is a part of the SCAN method of analysis.

\section{COMMITMENT TO CONTENT IN THE FORENSIC ANALYSIS OF WRITTEN STATEMENTS}

For the purpose of this study, and due to a limited scope of research, we will look into the Commitment to content, as one of the possible indictments of a deceitful statement. The aim of the analysis is to be able to define the common linguistic code of the author and then to distinguish from the fabricated segments of the author's statement.

Commitment to content is a criterium in the SCAN method that relates to the author attempting to distance him/herself from the propositional content in the written statement. It is infrequent that we generally utilize this strategy in discourse in order to hedge against the claims that we are making and it is no different in the form of the written statements. Hedging, as a metadiscourse strategy, is regarded 
as a frequent linguistic resource used by many and it falls under the category of strategic (language) competence of the individual.

\subsection{Strategic competence and metadiscourse markers}

Writing strategies are inextricably intertwined with the writing process. (Livingstone 2019: 245) Writers project themselves into their discourse to signal their understanding of their material and their audience. (Hyland 2010 in Livingstone 2019: 245) Strategic (language) competence relates to the specific language items used both in spoken and written communication to negotiate a meaning, to remedy a breakdown of a conversation or to appeal to the reader and his/her interpretation of the written text. As Hyland states (2005: 16) "Metadiscourse is an umbrella term used to include an apparently heterogeneous array of cohesive and interpersonal features which help to relate a text to its content." In the most comprehensive way Hyland (2005: 37) defines metadiscourse as "the cover term for the self-reflexive expressions used to negotiate interactional meanings in a text, assisting the writer (or speaker) to express a viewpoint and engage with readers and members of a particular community." This definition is important because it stresses a three-way relationship or association among the writer, the readership, and the interactive and interactional markers used to communicate information. (Livingstone 2019: 245)

\subsubsection{Interactional resources: hedging}

Following Thompson's (2001) distinction of metadiscourse markers into the interactive (language items assisting the readers in navigating through the text) and the interactional resources (language items involving the reader in the text), Hyland (2010: 4-5) proposes a detailed description of these categories in the Model of Metadiscourse Markers in Academic Tests.

In interactional resources (besides boosters, attitude markers, engagement markers and self-mentions) hedges are language items that are consciously applied by the speaker/writer and as such mould their discourse into an authentic form of expression. Hedging is a device used to reduce the intensity of an utterance and temper the impact of a declaration. (Livingstone 2019: 246) In speaking, Lyons (1997: 797, in Livingstone 2019: 246) defined hedging as "an item of language which a speaker uses to explicitly qualify his/her lack of commitment to the truth of a proposition he/she utters". Although this initially related to the act of speaking, in the written statement we are also prone to record instances of the author explicitly trying to distance $\mathrm{him} / \mathrm{herself}$ from the content, with the intention to reduce commitment towards the claims. Therefore, we may observe that hedges can be used to facilitate the addressee or to put emphasis on the accurateness of the information presented. (Talbot, 2010 in Livingstone 2019: 246) Regardless of 
the context in which we observe distancing and hedging, be it academic writing or forensic analysis of written statements, it is obvious that the author's intention is to explicitly present distancing in the text and the reader's task then is to detect the implicit meaning in this distancing strategy.

For this purpose, it is significant to further examine the hedging strategy of distancing before we observe hedging language items in the written reports in criminal investigation.

\subsubsection{Hedging in Forensic Linguistic Analysis}

As has previously been stated, speakers/writers intentionally use strategic language devices that enable them to distance themselves from the propositional content. In forensic analysis the use of distancing and hedging, pertaining to a refusal of commitment to the truth, is regarded as a negative 'writing move' and a purposeful attempt of deception. The analysis of written statements of suspects/ victims/witnesses should illuminate instances of distancing and hedging strategy and thus enable information for further interrogation process.

In Table 1 we present an overview of strategic distancing in writing in the field of forensic analysis through the SCAN method (Sapir 1996).

\begin{tabular}{|l|l|}
\hline \multicolumn{2}{|c|}{$\begin{array}{l}\text { Committing to a claim in } \\
\text { FORENSIC ANALYSIS }\end{array}$} \\
\hline $\begin{array}{l}\text { Lack of commitment to } \\
\text { content }\end{array}$ & $\begin{array}{l}\text { Use of person and/or tense other than } \\
1^{\text {st }} \text { person singular + past-time reference } \\
\text { Eg. I arrived there at 5 o'clock. I get out of the car and I see } \\
\text { that he is afraid of me. }\end{array}$ \\
\hline $\begin{array}{l}\text { Use of Active/Passive } \\
\text { voice }\end{array}$ & $\begin{array}{l}\text { Use of Passive voice confirms weaker commitment to the } \\
\text { claim/act } \\
\text { Eg. Then I heard the shot. I heard the shot in the distance. } \\
\text { Vs. } \\
\text { Then a shot was heard. A shot was heard in the distance. }\end{array}$ \\
\hline $\begin{array}{l}\text { Words/expressions for } \\
\text { lack of commitment }\end{array}$ & $\begin{array}{l}\text { Eg. approximately, I guess/suppose, I think, I believe, I } \\
\text { doubt, If I remember correctly...+ synonymous language } \\
\text { items }\end{array}$ \\
\hline
\end{tabular}

Table 1. (Lack) of Commitment to Content in Forensic Analysis 
As can be seen in Table 1, writing choices that the author makes can be observed through the forensic analysis. Authors infrequently establish a distance in writing by using words and expressions that remove/distance them from the commitment to the claim/act.

- Lack of commitment to content - The narrative format of a written statement is based on the subject's short/long-term memory recall. The Cognitive Interview (CI), as a common one conducted by the police officials, has the purpose of obtaining as much information as possible from a witness, without compromising accuracy of statement (Fisher \& Geiselman 1992; Geiselman \& Fisher in eds. Oxburgh, Myklebust, Grant \& Milne 2016: 81). The CI relies on the witness to provide the needed information via open-ended questions and so it is witness-centered, rather than interviewer-focused (Oxburgh, Myklebust, Grant \& Milne, eds. 2016: $82)$. By the use of an open-ended question the police official requires the witness to use the episodic memory and to recall the events of a specific day in the past. In terms of a linguistic item, the past narrative is expected to be delivered in the written statement with the $1^{\text {st }}$ person singular + past time reference and, according to Sapir (1996), any distancing from the expected $1^{\text {st }}$ person sing. and the past time reference is to be regarded as deceitful. The distancing here explicitly refers to the use of any other time reference, apart from the past time reference. Any observable fluctuation in the past time narrative format is regarded as an indictment for further police investigation.

- Use of Active/Passive Voice - This well-known grammar item is a common syntactic structure both in oral and written discourse. The Active Voice structure explicitly postulates the subject as the agent of the action and therefore explicitly exhibits commitment of the subject to content (ie. action). The Passive Voice, on the other hand, is a syntactic structure that we use when we want to defocus the agent and when the agent is not mentioned because it is redundant, unknown, very general, or if the speaker is being tactful or evasive (Celce-Murcia \& Larsen-Freeman 1999: 353). It is exactly these latter 2 uses of the Passive Voice that show direct and deliberate lack of commitment to content. In forensic linguistic analysis of written statements this use of the Passive Voice establishes the foreground for deception and is considered for further investigation.

- Words/Expressions for lack of commitment - Apart from the aforementioned syntactic structures that may imply that the witness/suspect/victim is deceitful, there are additional words and expressions that moderate the claim of the author and therefore exhibit lack of commitment to content. Distancing is also accomplished through the use of sensory verbs (I guess, I suppose, I think, I doubt, if I recall/remember...) or through quantifying 
words/expressions (approximately, not fully, rarely...) and other synonymous words and expressions. Although there may be instances when the subject cannot recall fully the segments of the episodic memory, in most cases he/she has a clear intention of deception or (sub)consciously distancing themselves from the content.

\section{RESEARCH FRAMEWORK}

The purpose of this study was to provide an insight into the applicability of forensic linguistic analysis in the field of criminology and law. Also, the purpose of the research in the study was to observe one of the SCAN criteria, namely Commitment to content, in the light of linguistic analysis of distancing and hedging, with the aim to offer possible clues to the investigation process in the form of suggested interrogation questions.

\subsection{Ethics Statement}

The study was supported by the European Forensic Agency and the written reports have been approved for scientific and publication analysis by EFA, in collaboration with the Ministry of Interior in Serbia. The written statements used for the forensic analysis are confidential and may only be used for educational, scientific research and publication purposes, respecting all the privacy aspects of the subjects involved in the cases. Therefore, any personal details in the statements (names, addresses, reference to dates etc.) have been altered in order to fully protect and conceal the identity of the subjects.

\subsection{Instruments and Methods of Research}

The instrument used in the analysis of the official police written statements of the suspects/victims/witnesses is the Commitment to content (Sapir 1996), as a language strategy that may indicate some form of deception. In linguistic analysis this criterium relates most closely to various forms of distancing/hedging and thus the analysis is based on these linguistic devices. The method of research was a quantifying and a descriptive one, with the purpose to identify the language items in focus, and a qualifying one, to interpret them in relation to the macro structure of the written text, distinguishing the truthful and the deceitful parts of the structure.

\subsection{Research procedure}

In this analysis we have selected an authentic, officially written statement of the accused in the case of sexual assault. We were granted access to the written 
statement by the European Forensic Agency in collaboration with the Ministry of Interior in Serbia. We have analyzed it according to the criteria of Commitment to content and in relation to the function of these linguistic features, which is to distance the author from the propositional content.

\section{RESULTS OF RESEARCH}

In the study we quantitatively and qualitatively analyzed the linguistic features of distancing the author from the propositional content. The process of forensic analysis had several procedural steps:

- first being the reading of the report and obtaining the general information about the case,

- the second being the marking scheme that is applied during the analysis (in the case of this criteria Lack of commitment to content and the use of Active/Passive voice were underlined and bolded and the use of Words/ Expressions for commitment were bolded) and

- finally, the last step is drawing conclusions about the recorded linguistic features and suggesting further questioning on specific parts of the report.

Below we present the written statement of the accused, translated into English, staying true to the original (Appendix 1), with all the grammatical and punctuation errors and correction instances. For confidentiality purposes specific dates, places and names have been left out or altered.

\section{CASE: Sexual assault, the accused}

I report that in the afternoon hours around 2 p.m. on d.m.y I eorreetion went to the store to Place, and later I was in my house at my aunt's for a coffee in the house next to mine. While I was on the Internet I watched TV somewhere around 10 p.m. my daughter Jane and her friend Lora came which were taking a walk and because it was cold outside they eorreetion came back to warm up. They were sitting in the living room and playing with their phones and watching $\mathrm{TV}$ at the same time. At one moment they asked me if we could make pancakes and I agreed with them after which they were making sandwiches in the kitchen and the pancake dough. I showed them how the electric pan works and I turned it on, and they continued preparing them while I was reading something on the Internet and watching TV, and they also joined me in the living room after they ate and finished their pancakes. After that they asked me to play cards with them and we were sitting on the bed because there was enough space for all and so that we wouldn't sit at the table on the chairs, and the TV was close to us and from there it could be watched from time to time while we played the cards. After that after approximately two hours we agreed that it was enough and Jane lied down to watch something on the phone and the TV and Lora asked me to massage her back because. it was hurting her and lied down next to Jane, and I sat next to Lora and massaged her for several minutes and after that I said that I couldn't sit any more eorrentionand that it was enough whe she agreed and said thank you. Then I got up and went to the kitchen to drink water, and they remained there lying 
on the bed in the living room, and after that to the bathroom to wash my hands and to wash my face and I went to the bedroom where I changed into a pyjamas and a T-shirt and went to sleep after which I soon fell asleep. At one moment I felt someone lifting the blanket I was covered with, and since I thought it was Jane I asked What is it Jane, what's the time? - because being sleepy I didn't know, and the window shields were almost closed eorreetion but not all the way to the end and it was looming as dawn, and then I heard Lora saying that it's not Jane but her and she tried to get under the blanket where I was lying. At that moment I jumped and got up from the bed all drowsy not knowing what time it was and why she was doing that and when I saw that it was 6 in the morning I told her to immediately go home and go to sleep there and not to get into my bed and that it would be better for her to leave the house immediately so that I would not have to inform her father about the situation that surprised me on her part. She then left the room and put her jacket on, she didn't say anything and she left the house.

In the written report we may observe that there are examples of all three linguistic features that relate to distancing: Lack of commitment by avoiding $1^{\text {st }}$ person singular + past tense reference, the use of Passive voice and the use of Words/ expressions for commitment. On the macrostructure of the text they evidently all appear in the entire structure in the following distribution:

Beginning of text:

Words/expressions for commitment (around, somewhere around)

Middle of the text:

Use of Passive Voice (could be watched, was hurting)

Words/expressions for commitment (approximately)

End of the text:

Lack of commitment by avoiding $1^{\text {st }}$ person singular + past time reference (it would be better, I would not have to inform)

Use of Passive Voice (were closed, was looming)

Words/expressions for commitment (almost)

As there is a more frequent occurrence from the middle of the report to the end of the text, it is exactly this segment of the written statement that we must observe more closely.

\section{DISCUSSION}

The occurrence of more instances of language devices that implicate distancing and lack of commitment in a specific part of the text indicates that the Main Issue (MI) of the case must have taken place in that part of the report. In the parts of the statement where the subject ran away from commitment, we conclude that this point/ area is sensitive for the subject. (Sapir 1996) The 'sensitive' area in the statement is usually 'framed' with the use of specific linguistic features, indicating the entrance into the criminal act and its closure (pertaining to consequences). 
Based on the analysis of the sexual assault case we may infer the following conclusions about the lack of commitment to content:

- The entrance into the MI took place from the moment the subjects sat on the bed to play cards;

- Distancing began when they all decided to stop playing cards;

- Massaging was the moment when there came an insinuation of the criminal act yet to come;

- Sexual harassment took place approximately in the morning hours around dawn;

- Consequences dawned upon the perpetrator following the sexual harassment when the girl was about to go home.

All of the provided conclusions from the forensic analysis may suggest that the police investigation should focus further on these specific times of the criminal act and on the specific details about the decision to sit on the bed, to massage the girl and the moment of dawn when the girl, allegedly voluntarily, went under the covers of the perpetrator and finally left the house. These insights from the forensic analysis, alongside with the other detected linguistic features of SCAN (that have not been the subject of this study) clearly indicate the framed criminal act in the text. The 'framed' criminal act after the analysis may provide the police officials with an insight to question the subject exactly on those specific times and to apply different methods of memory recall through a follow-up Cognitive Interview. Although we have only dealt with the Commitment to content, various marking methods for all other linguistic signals of SCAN, vividly label the second part of the text as the grounds for potential further interrogation process. This linguistic analysis contributes to possible lack of evidence in the case and is especially useful in the comparative analysis of written statements of the victim and the accused.

It is important to note that the selected written statement that was analyzed was only the first step in the police investigation and that the results were used for the preparing for the polygraph tests. The accused underwent polygraph testing after which the conclusive report indicated his allegations to be deceitful and he was processed for further police investigation in the case.

\section{CONCLUSION}

The central purpose of this study was to define and illustrate forensic linguistic analysis and the possibilities it serves for law enforcement and criminal application. We presented how forensic linguistics research is undertaken in fields as diverse as language and memory studies, Conversation Analysis, Discourse Analysis, theory of grammar, Cognitive Linguistics, Speech Act Theory, etc. All of these different 
fields of analysis have a similar goal which is to establish the linguistic code of the subject and, based on it, to detect instances in the written statements that exhibit changes from this linguistic code.

For the purpose of this study we reflected on Scientific Content Analysis (SCAN), as one of the most applicable forensic analysis methods used in Australia, Belgium, Canada, Israel, Mexico, UK, US, the Netherlands, Qatar, Singapore, South Africa, mostly by federal agencies, military law enforcement, private corporations and social services. The selected criterium of Commitment to content was first observed in the field of Forensic analysis in order to distinguish the purpose and nature of distancing in written statements. This criterium was analyzed more closely, defining the distancing means of linguistic devices and finally it was used as an instrument in the analysis of the official written statement, provided by the European Forensic Agency, in collaboration with the Ministry of Interior in Serbia. In this statement, based on the sexual assault case, we analyzed the Commitment to content criterium through the linguistic features of distancing and hedging in SCAN method and we were able to infer conclusions about the criminal act and the timed framing of its occurrence according to the provided statement. Frequent occurrence of the linguistic features of distancing in the specific part of the report indicated the approximate time of the beginning and the end of the criminal act, as well as the context within which it occurred. These specific details allowed for the conclusions about the possible content questions that were further to be applied in the interrogation process.

The implications of this study may lie in the scientific contribution to the field of forensic linguistics, as well as the application process in the police investigation process. In the lack of more scientific papers on this content, future research may involve linguistic analysis of separate SCAN criteria on various official cases and a comparative approach to analysis in different languages due to the possibility of attaining alternate results in various language systems and therefore different interpretive conclusions and analysis implications.

\section{Appendix 1}

Izjavljujem da sam dana dd.m.gggg. god. u popodnevnim satima oko $14 \mathrm{~h}$ bibo do prodavnice na Mesto1, a kasnije sam bio u kući i kod tetke na kafu u kući pored moje. Dok sam bio na internetu I gledao tv negde oko $22 \mathrm{~h}$ su došle moja ćerka Žimel i njena drugarica Žime2 koje su bile u šetnju i pošto je bilo hladno napolju vratidošle su da se zgreju. Sedele su u dnevnoj sobi i igrale se svojim telefonima i ujedno gledale tv. U jednom trenutku su me pitale da li možemo da pravimo palačinke i ja sam se složio sa njima nakon čega su one spremale u kuhinji sendviče da prezalogaje i smešu za palačinke. Ja sam im pokazao kako radi električni tiganj i uključio sam ga, a one su nastavile sa pravljenjem dok sam ja čitao nešto na internetu i gledao televizor, a i one su mi se pridružile takođe tu u dnevnoj sobi nakon što su jele i završile sa palačinkama. Nakon toga su me pitale da igram karte s njima i sedeli smo na krevetu pošto je bilo mesta za sve da ne bi sedeli za stolom in a stolicama, a i televizor nam je bio tu u blizini 
i odatle je mogao da se gleda s vremena na vreme dok se igraju karte. Posle toga nakon nekih dva sata otprilike smo se složili da je dosta bilo i Žimel se ispružila da gleda nešto na telefon i televizor a Žime2 je pitala da joj izmasiram leđa jer. je bole i legla pored Žimel, a ja sam seo pored Žime 2 i izmasirao je nekoliko minuta i posle toga sam rekao da ne mogu više da sedim je-i da je dosta na šta je ona sa čim se i ona složila i rekla hvala. Zatim sam ustao i otišao do kuhinje da pijem vodu, a one su ostale tu na krevetu u dnevnoj sobi da leže, a posle toga do kupatila da operem ruke i da umijem i otišao sam u spavaću sobu gde sam se presvukao u pižame i majicu I lego da spavam nakon čega sam se ubrzo i uspavao. U jednom momentu sam osetio kako neko podiže ćebe kojim sam se pokrio, a pošto sam mislio da je Žimel upitao sam je: Šta je bilo Žime1, koliko je sati? - jer nisam onako sanjiv to znao, a roletne a su bile skoro spuštene do ali ne skroz do kraja i naziralo se kao da je svanulo, a onda sam čuo Žime 2 kako kaže da nije Žimel već ona i pokušala je da se uvuče ispod ćebeta tu de sam ležao. U tom momentu sam se trgo i ustao iz kreveta onako sanjiv ne znajući koliko je sati i zašto to radi i kad sam video da je oko 6h ujutru rekao sam joj da odmah ide kući i da tamo legne da spava a ne to da se uvlači kod mene u krevet i da joj je bolje da izađe iz kuće odmah da ne bih morao da obavestim njenog oca o situaciji koja me je iznenadila sa njene strane. Ona je tada izašla iz sobe i obukla jaknu, ništa nije rekla i izašla je iz kuće.

\section{CORPUS}

Official written statement by the accused, provided by the European Forensic Agency (EFA) in collaboration with the Ministry of Interior, Serbia.

\section{LITERATURE}

Bogaard Glynis, Meijer H. Ewout, Vrij Aldert \& Merckelbach Harald 2016: Scientific Content Analysis (SCAN) Cannot Distinguish Between Truthful and Fabricated Accounts of a Negative Event, Frontiers in Psychology, Volume 7, article 243, 1-7.

Celce-Murcia Marianne \& Larsen-Freeman Diane 1999: The Grammar Book, An ESL/EFL Teacher'S Course, $2^{\text {nd }}$ ed., Heinle \& Heinle Publishers.

Coulthard Malcolm \& Johnson Alison 2007: An Introduction to Forensic Linguistics, Language in Evidence, Routledge: Taylor \& Francis Group.

Coulthard Malcolm, Johnson Alison \& Wright David 2017: An Introduction to Forensic Linguistics, Language in Evidence, $2^{\text {nd }}$ ed., Routledge: Taylor \& Francis Group.

Houtman Houtman \& Suryati Ali 2018: The History of Forensic Linguistics as an Assisting Tool in the Analysis of Legal Terms, Sriwijaya Law Review, Vol. 2, Issue 2, 215-232.

Hyland Ken \& Tse Polly 2004: Metadiscourse in Academic Writing: A Reappraisal, Applied Linguistics, 25(2), 156-177. 
Hyland Ken 2005: Metadiscourse: Exploring Interaction in Writing, Londong: Continuum.

Livingstone A. Kerwin 2019: Examining the Use of Metadiscourse Markers in Academic Writing, International Journal of Literature, Language and Linguistics, Vol. 5(3), 244-254.

McMenamin R. Gerald 2002: Forensic Linguistics: Advances in Forensic Stylistics, Boca Raton: CRC Press.

Nikolić Lidija 2017: Forenzička lingvistika, Primena metoda forenzičke lingvistike u kriminalističkim istragama pretnje, Banja Luka: Evropski Defendologija Centar.

Olsson John 2008: Forensic Linguistics: Second Edition, New York: John Olsson.

Oxburgh Gavin, Myklebust Trond, Grant Tim \& Milne Rebecca eds. 2016: Communication in Investigative and Legal Contexts, Integrated Approaches from Forensic Psychology, Linguistics and Law Enforcement, West Sussex: John Wiley \& Sons, Ltd.

Sapir Avinoam 1996: The LSI SCAN Workshop Guidebook: Scientific Content Analysis, Phoenix, AZ: Laboratory for Scientific Interrogation.

Smith Nicky 2001: Reading between the lines: An evaluation of the Scientific Content Analysis technique (SCAN), London: Crown.

Thompson Geoff 2001: Interaction in Academic Writing: Learning to Argue with the Reader, Applied Linguistics, 22(1), 58-78.

Swales M. John \& Feak B. Christine 1994: Academic Writing for Graduate Students, Michigan: University of Michigan Press.

\section{ПРЕПОЗНАВАЬЕ ОБМАНЕ КРОЗ ОГРАЪИВАЬЕ У ФОРЕНЗИЧКОЈ АНАЛИЗИ ПИСАНИХ ИЗЈАВА}

$$
\text { Резиме }
$$

Форензичка лингвистика је поље лингвистичке анализе дискурса, са применом у правним поступцима и криминалистичкој истрази. Лингвистичка анализа пружа основу за форензичку истрагу која може довести до значајних закључака у психоанализи понашања и менталних процеса испитаника. Путем језичке анализе у писаном дискурсу могуће је препознати језички код аутора и на тај начин установити одступања од његове/њене језичке норме. Ова одступања можемо посматрати као индикаторе лажи код испитаника због недостатка обавезивања испитаника према свом садржају/исказу. Ова врста избегавања и необавезивања према садржају у писаном 
дискурсу често се постиже употребом метадискурсних маркера ограђивања. У овом раду посматрамо језичке елементе ограђивања и њихову сврху употребе на пољу Форензичке анализе, а потом анализирамо званичну писану изјаву блудних радњи, која је била део полицијске истраге у Министарству унутрашњих послова Републике Србије, како бисмо установили на који начин употреба ограђивања може бити показатељ обмане. Резултати указују на чињеницу да је сврха ограђивања у форензичкој анализи другачија у погледу појаве у структури текста и у односу на критично дело (енг. Main Issue). Резултати упућују на закључак да је ограђивање показатељ обмане и да на тај начин форензичка лингвистичка анализа може допринети даљем развоју криминалистичког поступка.

Кључне речи: форензичка лингвистика, форензичка анализа писаних изјава, стратешка компетенција, обавезивање према садржају, ограђивање.

Бранка Л. Миленковић 